\title{
The Trans-Hudson Orogen of North America and the Himalaya- Karakoram-Tibetan Orogen of Asia: Structural and thermal evolution of the collisional lower and upper plates
}

\author{
Marc St-Onge ${ }^{1 *}$, Michael Searle ${ }^{2}$, Natasha Wodicka ${ }^{1}$, Jeroen van Gool ${ }^{3}$, \\ Adam Garde ${ }^{3}$ and David Scott ${ }^{1}$ \\ 1 Geological Survey of Canada, Natural Resources Canada, Ottawa K1A OE8, CANADA \\ 2 Department of Earth Sciences, University of Oxford, Oxford OX1 3PR, UK \\ 3 Geological Survey of Denmark and Greenland, Copenhagen-K 1350, DK \\ * For correspondence, email: mstonge@nrcan.gc.ca
}

The Trans-Hudson Orogen (THO) of North America and the Himalaya-Karakoram-Tibetan Orogen (HKTO) of Asia preserve a Paleoproterozoic and Cenozoic record, respectively, of continentcontinent collision that is notably similar in scale, duration, and character (St-Onge et al. 2006). In THO, the tectonothermal evolution of the lower-plate involves (1) early thin-skinned thrusting and Barrovian metamorphism, (2) out-of-sequence thrusting and high-T metamorphism, and (3) fluid-localized reequilibration, anatexis and leucogranite formation. The crustal evolution of the Indian lower-plate in HKTO involves (1) early subduction of continental crust to UHP (ultra-high pressure) eclogite depths, (2) regional Barrovian metamorphism, and (3) widespread high-T metamorphism, anatexis and leucogranite formation. The shallow depths of the high-T metamorphism in HKTO are consistent with early to mid-Miocene ductile flow of an Indian lower-plate mid-crustal channel, from beneath the southern Tibetan plateau to the Greater Himalaya. Melt weakening (Jamieson et al. 2004) of the lower-plate in THO is not observed at a similar scale probably due to the paucity of pelitic lithologies, and consequently formation of a mid-crustal channel is not required to account for the documented tectonothermal evolution of THO's lower plate.

Tectonothermal events in the upper-plate of both orogens include pre-collisional accretion of crustal blocks, with for example the North Atlantic craton of Greenland and Canada being in a similar tectonic position to the South China block in Asia (St-Onge et al., 2008), emplacement of cumulative Andean-type plutonic suites, and consequent, multiple phases of high-T metamorphism (St-Onge et al. 2007). Syn- to post-collisional events include emplacement of garnet-biotite-muscovite leucogranites, anatectic granites, and sporadic metamorphism (up to $90 \mathrm{Ma}$ following the onset of collision in THO). Comparing the type and duration of tectonothermal events for THO and HKTO supports the notion of tectonic uniformitarianism for at least the later half of dated Earth history (from the early to middle Paleoproterozoic onward), and highlights the complementary nature of the rock record in an older "exhumed" orogen compared to one undergoing present day orogenesis.

\section{References}

Jamieson RA, C Beaumont, S Medvedev and MH Nguyen. 2004. Crustal channel flows: 2. Numerical models with implications for metamorphism in the Himalayan-Tibetan orogen. Journal of Geophysical Research 109: B06406, doi:10.1029/2003JB002811

St-Onge MR, MP Searle and N Wodicka. 2006. Trans-Hudson Orogen of North America and Himalaya-Karakoram-Tibetan Orogen of Asia: Structural and thermal characteristics of the lower and upper plates. Tectonics 25: doi:10.1029/2005TC001907, $22 \mathrm{p}$

St-Onge MR, N Wodicka and O Ijewliw. 2007. Polymetamorphic evolution of Trans-Hudson Orogen on Baffin Island, Canada: contraints from petrology, structure and geochronology. Journal of Petrology 48: doi:1093/petrology/eg1060, 32p

St-Onge, MR, JAM van Gool, AA Garde and DJ Scott. 2008. Correlation of Archaean and Palaeoproterozoic units between northeastern Canada and western Greenland: constraining the pre-collisional upper plate accretionary history of the Trans-Hudson orogen. Geological Society of London Special Publication, (in press). 